\title{
Down-regulation of transforming growth factor $B$ receptor type III in hepatocellular carcinoma is not directly associated with genetic alterations or loss of heterozygosity
}

\author{
HYUN JIN BAE，JUNG WOO EUN，JI HEON NOH，JEONG KYU KIM，KWANG HWA JUNG, \\ HONG JIAN XIE, WON SANG PARK, JUNG YOUNG LEE and SUK WOO NAM \\ Department of Pathology, Microdissection Genomics Research Center, \\ College of Medicine, The Catholic University of Korea, Seoul 137-701, Korea
}

Received May 5, 2009; Accepted June 24, 2009

DOI: $10.3892 /$ or_00000459

\begin{abstract}
The transforming growth factor receptor III (TGFßRIII) is the most abundant and essential TGF- $\beta$ binding protein that functions as a co-receptor with other receptors in TGF- $\beta$ signaling. In earlier studies, expression of TGFßRIII was reported to be decreased in a variety of human cancers. Functional assessment of TGFßRIII was performed in many previously studied cancers but not in hepatocellular carcinoma. Therefore, in this study, we investigated the expression and genetic alterations of TGFßRIII in hepatocellular carcinoma (HCC) by quantitative real-time PCR (qRT-PCR) and singlestrand conformation polymorphism (SSCP) analysis. The qRT-PCR showed down-regulation of TGFßRIII in the tumor samples. To investigate whether genetic alterations mediated decreased expression of TGFßRIII, we performed mutation analysis of 67 human HCC tissues by SSCP and direct sequencing. We found five previously reported and one novel single nucleotide polymorphisms in exons 2, 3, 5, 13 and 14, but no mutations were detected. These polymorphisms were not associated with amino acid changes except for a base change found in exon 2 (TCC $\rightarrow$ TTC, S15F). The loss of heterozygosity $(\mathrm{LOH})$ analysis performed on 10 tumors and corresponding normal pairs, showed a low rate of $\mathrm{LOH}$ $(2 / 10)$. The results of this study suggest that TGFßRIII is transcriptionally down-regulated in hepatocellular carcinoma. In addition, genetic alterations did not appear to be associated with the reduced expression level of TGFßRIII. To clarify the role of TGFßRIII in hepatocellular tumor development and progression, functional analysis is needed in future studies.
\end{abstract}

Correspondence to: Dr Suk Woo Nam, Department of Pathology, College of Medicine, The Catholic University of Korea, \#505 Banpo-dong, Seocho-gu, Seoul 137-701, Korea

E-mail: swnam@catholic.ac.kr

Key words: transforming growth factor $\beta$ receptor III, hepatocellular carcinoma, mutation, loss of heterozygosity

\section{Introduction}

Hepatocellular carcinoma (HCC) is the fifth most common cancer; the associated mortality is the third highest among cancers. HCC is one of the main causes of cancer-related death in Asia and Africa (1). Hepatitis B virus (HBV), hepatitis C virus $(\mathrm{HCV})$ and aflatoxin $\mathrm{B} 1$ are well known major causative agents of $\mathrm{HCC}$. However, the underlying mechanisms involved in the development and progression of HCC remain poorly understood (2). Previous studies have reported that genetic alterations of tumor associated genes such as p53, $\beta$-catenin and AXIN1 are involved in hepatocarcinogenesis (3-5); however, the frequencies of mutations in these genes appear to be very low in patients with HCC. Furthermore, it is unclear how these genetic changes precisely cause the clinical characteristics observed in individual patients with HCC. Therefore, the major molecular events underlying HCC remain to be identified.

The transforming growth factor $\beta$ (TGF- $\beta$ ) family consists of diverse structurally related growth factors that regulate a wide variety of cellular processes including cell proliferation, lineage determination, differentiation, motility, adhesion and death (6). There are three TGF- $\beta$ isoforms (TGF- $31-3$ ) that exert their role by binding to three types of receptors: type I (TGFßRI), type II (TGFßRII) and type III (TGFßRIII) (7). TGF- $\beta$ signaling, is characterized by ligand binding to TGFßRII, continuously active serine/threonine kinase, recruitment and phosphorylation of TGFßRI (8). Activated TGFßRI transmits signaling by activating Smad 2 or Smad 3, which form a complex with Smad $4(8,9)$. The Smad complex then translocates to the nucleus to activate the target genes in a cell-specific manner $(6,7,9)$.

The transforming growth factor $\beta$ receptor type III (TGFßRIII, also called betaglycan) consists of 849 amino acids with a short cytoplasmic tail that includes 41 amino acid residues (10). TGFßRIII is the most abundant TGF- $\beta$ receptor; it is regarded as a co-receptor that presents ligands to TGFßRII, thought to be due to the absence of a signaling motif $(10,11)$. There is considerable evidence implicating TGFßRIII in a variety of human cancers. Down-regulation of TGFßRIII expression has been reported in renal cell carcinoma and endometrial carcinoma $(12,13)$. Moreover, in addition to the loss of expression, a tumor suppressing role 
of TGFßRIII has been suggested in breast, prostate and non-small cell lung cancers (14-16). However, no such studies have been performed to date in human HCC. In addition, DNA micro-array data, from our previous study, indicated that the expression of TGFßRIII was gradually down-regulated from the pre-cancer state to overt cancer in HCC compared to corresponding normal tissues (17), suggesting a possible role of TGFßRIII in hepatocarcinogenesis.

Therefore, in this study, we investigated the differential gene expression of TGFßRIII in tumor and normal paired tissue samples and the genetic alterations of the TGFßRIII gene in 67 hepatocellular carcinoma cases by quantitative real-time PCR (qRT-PCR), single-strand conformation polymorphism (SSCP) and sequencing and loss of heterozygosity $(\mathrm{LOH})$ analysis.

\section{Materials and methods}

Tissue samples. Sixty-seven frozen HCCs and their corresponding background normal tissue samples obtained from 67 patients at resection were evaluated. Approval was obtained from the Institutional Review Board of College of Medicine, The Catholic University of Korea and informed consent was obtained beforehand in accord with the requirements of the Declaration of Helsinki. There was no evidence of familial cancer in any of the patients. The ages of the patients ranged from 4-74 (average 55 years) and there were 48 men and 19 women. The background liver demonstrated the presence of cirrhosis in $24(35.8 \%)$ cases, chronic hepatitis in $40(59.7 \%)$ and no specific change in $3(4.5 \%)$. HBV was detected in $51(76.1 \%)$ and $\mathrm{HCV}$ in 4 patients $(6 \%)$. Histologically, 1, 39 and 27 samples were Edmonson grades I, II and III, respectively.

Cell culture. Ten HCC cell lines, HepG2, Hep3B, PLC/PRF/5, SNU-182, SNU-354, SNU-368, SNU-387, SNU-423, SNU449 and SNU-475 were cultured in RPMI-1640 medium (Lonza, Walkersville, MD, USA) containing 10\% fetal bovine serum (Lonza) and 1\% penicillin/streptomycin (Invitrogen, Carlsbad, CA, USA). An immortalized normal liver cell line, THLE3, was maintained in BEBM medium (Lonza) supplemented with the BEGM Bullet kit and $10 \%$ fetal bovine serum (Lonza).

DNA extraction. Frozen tissue samples were ground to a fine powder in liquid nitrogen and this powder was incubated overnight in $500 \mu \mathrm{l}$ of lysis buffer $(5 \mathrm{mM}$ Tris- $\mathrm{Cl} \mathrm{pH} \mathrm{8.0,}$ $20 \mathrm{mM}$ EDTA, $0.5 \%$ Triton X-100) containing $500 \mu \mathrm{g} / \mathrm{ml}$ of proteinase K (Takara Bio Inc., Shiga, Japan) at $50^{\circ} \mathrm{C}$. Eleven cell lines were lyzed with the same buffer in the presence of $100 \mu \mathrm{g} / \mathrm{ml}$ of proteinase $\mathrm{K}$ (Takara Bio Inc). Phenol: chloroform: isoamyl alcohol (25:24:1) solution (SigmaAldrich Corp., St. Louis, MO, USA) was then added to each lysate and after centrifugation $\left(15,000 \mathrm{rpm}, 4^{\circ} \mathrm{C}, 30 \mathrm{~min}\right)$, phenol: chloroform: isoamyl alcohol $(25: 24: 1)$ solution was added to the supernatants. DNA was precipitated with ethanol at $-70^{\circ} \mathrm{C}$ and washed with $70 \%$ ethanol. The dried pellets were resuspended with $1 \mathrm{X}$ TE buffer (10 mM Tris-Cl pH 8.0, $1 \mathrm{mM}$ EDTA).
Quantitative real-time PCR ( $q R T-P C R)$. Total RNA was isolated from frozen tissues using TRIzol reagent (Invitrogen) according to the manufacturer's instructions. cDNA was synthesized with the transcriptor first-strand cDNA synthesis kit (Roche Applied Science, Indianapolis, IN, USA). Realtime PCR analysis was performed in a total volume of $12.5 \mu 1$ mixture containing $3 \mu \mathrm{l}$ of 50 -fold diluted cDNA, $0.4 \mathrm{pM}$ of sense and antisense primers and $6.25 \mu 1$ of $\mathrm{iQ}^{\mathrm{TM}} \mathrm{SYBR}^{\circledR}$ Green supermix (Bio-Rad Laboratories, Hercules, CA, USA). To normalize differences in the amount of total cDNA added to each reaction, glyceraldehyde 3-phosphate dehydrogenase (GAPDH) gene expression was used as an endogenous control. The reaction mixture was denatured for $3 \mathrm{~min}$ at $95^{\circ} \mathrm{C}$ and incubated for 40 cycles (denaturing for $15 \mathrm{sec}$ at $95^{\circ} \mathrm{C}$, annealing for $20 \mathrm{sec}$ at $62^{\circ} \mathrm{C}$ and extention for $20 \mathrm{sec}$ at $72^{\circ} \mathrm{C}$ ). The primers used in the experiment were as follows: TGFßRIII (sense 5'-ACCGTGATGGGCATTGCGTT TGCA-3'; antisense 5'-GTGCTCTGCGTGCTGCCGATGC TGT-3') and GAPDH (sense 5'-ACCAGGTGGTCTCCTCT GAC-3'; antisense 5'-TGCTGTAGCCAAATTCGTTG-3'). The PCR was monitored in real-time using an $\mathrm{iQ}^{\mathrm{TM}}-5$ (Bio-Rad Laboratories) that allowed determination of the threshold cycle $(\mathrm{Ct})$ at the time exponential amplification of the PCR products began. The average $\mathrm{Ct}$, from duplicate assays, was used for further calculation and GAPDH-normalized gene expression was determined using the relative quantification method described as the following: Relative expression levels normalized to GAPDH $=2$-(TGFBRIII Ct-GAPDH Ct) $\mathrm{x} 100$. The results are expressed as the mean value of duplicates.

Single-strand conformation polymorphism and DNA sequencing. Genomic DNA samples from cell lines and HCC tissues were amplified with 21 sets of primers covering all of the coding regions of the TGFßRIII gene (Table I). The PCRs were performed under conditions with $10 \mu 1$ reaction mixtures containing $10 \mathrm{ng}$ of template DNA, $0.1 \mathrm{mM}$ of each deoxynucleotide triphosphate (Promega, Madison, WI, USA), $1.5 \mathrm{mM}$ of $\mathrm{MgCl}_{2}, 0.5$ unit of Ampli Taq gold polymerase, $1 \mu 1$ of 10X buffer (Perkin-Elmer, Foster City, CA, USA) and $1 \mu \mathrm{Ci}$ of $\left[{ }^{32} \mathrm{P}\right] \mathrm{dCTP}$ (Amersham, Buckinghamshire, UK). The reaction mixtures were initially denatured for $12 \mathrm{~min}$ at $95^{\circ} \mathrm{C}$, then subjected to 40 amplification cycles (denaturing for $30 \mathrm{sec}$ at $95^{\circ} \mathrm{C}$, annealing for $30 \mathrm{sec}$ at $49-54^{\circ} \mathrm{C}$ and extension for $30 \mathrm{sec}$ at $72^{\circ} \mathrm{C}$ ) and a final extension for $5 \mathrm{~min}$ at $72^{\circ} \mathrm{C}$. After amplification, the PCR products were denatured for $5 \mathrm{~min}$ at $95^{\circ} \mathrm{C}$, in a $1: 1$ dilution of sample buffer containing $98 \%$ formamide $/ 5 \mathrm{mmol} / \mathrm{l} \mathrm{NaOH}$ and loaded onto an SSCP gel (Mutation Detection Enhancement, FMC BioProduct, Rockland, ME, USA) with $10 \%$ glycerol. After electrophoresis, the gels were transferred to $3 \mathrm{MM}$ Whatman paper and dried. Autoradiography was performed using Kodak X-OMAT film (Eastman Kodak, Rochester, NY, USA). To detect mutations, the DNAs showing mobility shifts were excised from the dried SSCP gels and re-amplified over 40 cycles using the same primer sets. After electrophoresis in $2 \%$ agarose gels, the PCR products were eluted from the gels with the Qiaquick gel extraction kit (Qiagen, Valencia, CA, USA) following the manufacturer's instructions. Sequencing of the PCR products was performed by COSMO Co., Ltd (Seoul, Korea). 
Table I. Primer sequences for amplifying the coding region of the TGFßRIII gene.

\begin{tabular}{|c|c|c|}
\hline Exon & Nucleotide sequence & $\begin{array}{l}\text { Product } \\
\text { size (bp) }\end{array}$ \\
\hline $\begin{array}{l}\text { E2F } \\
\text { E2R }\end{array}$ & $\begin{array}{l}\text { 5'-CTGAAGTGACTGGACGAGA-3' } \\
\text { 5'-CCTGGGTAACAGAGTGAAAC-3' }\end{array}$ & 200 \\
\hline $\begin{array}{l}\text { E3-1F } \\
\text { E3-1R }\end{array}$ & $\begin{array}{l}\text { 5'-TGATCACCCTTGCCCCTTTG-3' } \\
\text { 5'-TGCAGTGCGGAGATTCAGGA-3' }\end{array}$ & 229 \\
\hline $\begin{array}{l}\text { E3-2F } \\
\text { E3-2R }\end{array}$ & $\begin{array}{l}\text { 5'-GTTTTGTCAGGCTGTGC-3' } \\
\text { 5'-GTTGAACCCCAGAAGAGA-3' }\end{array}$ & 199 \\
\hline $\begin{array}{l}\text { E4F } \\
\text { E4R }\end{array}$ & $\begin{array}{l}\text { 5'-TTTCTGCCCTCTTTCTGTT-3' } \\
\text { 5'-CCATTATGTCCTTGTGCTAAG-3' }\end{array}$ & 217 \\
\hline $\begin{array}{l}\text { E5-1F } \\
\text { E5-1R }\end{array}$ & $\begin{array}{l}\text { 5'-AGGTTCGATTTACAAGCA-3' } \\
\text { 5'-TTAACAGATGTTCVATTTCCA-3' }\end{array}$ & 202 \\
\hline $\begin{array}{l}\text { E5-2F } \\
\text { E5-2R }\end{array}$ & $\begin{array}{l}\text { 5'-CAGCAAACTTCTCCTTGA-3' } \\
\text { 5'-ATTGCCTGTCATAAATCAGT-3' }\end{array}$ & 200 \\
\hline $\begin{array}{l}\text { E6F } \\
\text { E6R }\end{array}$ & $\begin{array}{l}\text { 5'-CCTCAGTGGTTTGACAGATT-3' } \\
\text { 5'-TCATCTCTTGTCACACTCACA-3' }\end{array}$ & 245 \\
\hline $\begin{array}{l}\text { E7F } \\
\text { E7R }\end{array}$ & $\begin{array}{l}\text { 5'-AACTTTCTGGCATGTAGGTC-3' } \\
\text { 5'-GACATGCTCCACCAACTT-3' }\end{array}$ & 217 \\
\hline $\begin{array}{l}\mathrm{E} 8-1 \mathrm{~F} \\
\mathrm{E} 8-1 \mathrm{R}\end{array}$ & $\begin{array}{l}\text { 5'-ATTTTAGACTCATGAGTGATTT-3' } \\
\text { 5'-GCCATTGTGTATGAAGTTAT-3' }\end{array}$ & 188 \\
\hline $\begin{array}{l}\mathrm{E} 8-2 \mathrm{~F} \\
\mathrm{E} 8-2 \mathrm{R}\end{array}$ & $\begin{array}{l}\text { 5'-CCAAATCAATAAGAGATGAC-3' } \\
\text { 5'-GAAATGACAGTTCCTCACT-3' }\end{array}$ & 213 \\
\hline $\begin{array}{l}\text { E9-1F } \\
\text { E9-1R }\end{array}$ & $\begin{array}{l}\text { 5'-GGCCTGGCATCAAACACT-3' } \\
\text { 5'-GAGCCCATCTTCTCCСТCTT-3' }\end{array}$ & 235 \\
\hline $\begin{array}{l}\text { E9-2F } \\
\text { E9-2R }\end{array}$ & $\begin{array}{l}\text { 5'-CCGTTTCCTTTCCCAGAT-3' } \\
\text { 5'-TAGCCTCTCTTCCCTCCTG-3' }\end{array}$ & 246 \\
\hline $\begin{array}{l}\text { E10F } \\
\text { E10R }\end{array}$ & $\begin{array}{l}\text { 5'-ACAGAACTGCCTGTGGG-3' } \\
\text { 5'-CAAAGCTTTGTTCTGGAAAA-3' }\end{array}$ & 231 \\
\hline $\begin{array}{l}\text { E11F } \\
\text { E11R }\end{array}$ & $\begin{array}{l}\text { 5'-AGGCAGAACCAAACACA-3' } \\
\text { 5'-ACCCCCTACTGATAACAAAC-3' }\end{array}$ & 233 \\
\hline $\begin{array}{l}\text { E12F } \\
\text { E12R }\end{array}$ & $\begin{array}{l}\text { 5'-CCTGTGGGTTGTTATTTCC-3' } \\
\text { 5'-AAGGTCAAGGCTAACTTTCAG-3' }\end{array}$ & 208 \\
\hline $\begin{array}{l}\text { E13-1F } \\
\text { E13-1R }\end{array}$ & $\begin{array}{l}\text { 5'-TTGTGCCTAAAGTGAAAGTG-3' } \\
\text { 5'-TCAGCTTGCGGGATAG-3' }\end{array}$ & 243 \\
\hline $\begin{array}{l}\text { E13-2F } \\
\text { E13-2R }\end{array}$ & $\begin{array}{l}\text { 5'-GAAATTCTACAGTCCCAAGA-3' } \\
\text { 5'-CTAAAAATGCCAAAATAACC-3' }\end{array}$ & 215 \\
\hline $\begin{array}{l}\text { E14F } \\
\text { E14R }\end{array}$ & $\begin{array}{l}\text { 5'-CCCTGATTCTGTGCTTTGT-3' } \\
\text { 5'-TCTGATCGTGCCTCCC-3' }\end{array}$ & 180 \\
\hline $\begin{array}{l}\text { E15F } \\
\text { E15R }\end{array}$ & $\begin{array}{l}\text { 5'-GTTTCTGCTGAGACTTTGAT-3' } \\
\text { 5'-CCCAGGAGGTTTTATTTC-3' }\end{array}$ & 164 \\
\hline $\begin{array}{l}\text { E16F } \\
\text { E16R }\end{array}$ & $\begin{array}{l}\text { 5'-TGATGCAGACTAACCAAAA-3' } \\
\text { 5'-AAGCTGTTCACCAACTCTTA-3' }\end{array}$ & 196 \\
\hline $\begin{array}{l}\text { E17F } \\
\text { E17R }\end{array}$ & $\begin{array}{l}\text { 5'-TGCGTCTTTCTCTGACTCTG-3' } \\
\text { 5'-TGGCAGTAGCTGAGCTGA-3' }\end{array}$ & 219 \\
\hline
\end{tabular}

Loss of heterozygosity ( $\mathrm{LOH}$ ) analysis. The tumor and the corresponding normal DNA were amplified with the D1S188, D1S406, D1S435 and D1S2804 markers. PCR was
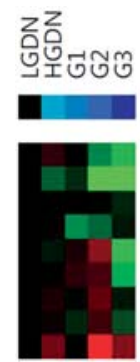

TGFB1I1 transforming growth factor beta 1 induced transcript 1 TGFBR3 transforming growth factor, beta receptor III

TGFB2 transforming growth factor, beta 2

TGFB3 transforming growth factor, beta 3

TGFA transforming growth factor, alpha

TGFA transforming growth factor, alpha

TGFBI transforming growth factor, beta-induced

TGFB1 transforming growth factor, beta 1
TGFBR1 transforming growth factor, beta receptor I

Figure 1. Heat-map of the differential expression of TGF- $\beta$ and TGF- $\beta$ receptors in a dysplastic HCC nodule. TGFßRIII is down-regulated during the progression of HCC. LGDN, Low-grade dysplastic nodule; HGDN, High-grade dysplastic nodule; G1-3, Edmonson grade 1-3. Red or green color indicates comparative over- or underexpression compared to the mean value of the indicated gene expression by DNA microarray data.

performed in $10 \mu \mathrm{l}$ reaction mixtures containing $10 \mathrm{ng}$ of template DNA, $0.1 \mathrm{mM}$ of each deoxynucleotide triphosphate (Promega), $1.5 \mathrm{mM}$ of $\mathrm{MgCl}_{2}, 0.5$ unit of Ampli Taq gold polymerase and $1 \mu \mathrm{l}$ of $10 \mathrm{X}$ buffer (Perkin-Elmer) and $1 \mu \mathrm{Ci}$ of $\left.{ }^{32} \mathrm{P}\right] \mathrm{dCTP}$ (Amersham). The PCR products were then denatured and electrophoresed in $6 \%$ polyacrylamide gel containing $7 \mathrm{M}$ urea. After electrophoresis, the gels were transferred to $3 \mathrm{MM}$ Whatman paper and dried. Autoradiography was performed using Kodak X-OMAT film (Eastman Kodak). Identification of complete absence of one allele, in the tumor DNA of informative cases, by direct visualization, was considered LOH.

\section{Results}

Aberrant regulation of TGFßRIII in HCC. Our previous findings showed that TGF- $\beta$ and the TGF- $\beta$ receptor family were differentially regulated during the progression of HCC (17). TGFßRIII was gradually down-regulated from a dysplastic nodule, a precancerous region of the $\mathrm{HCC}$, to Edmonson grades of HCC and overt HCC (Fig. 1). To validate the findings from the microarray analysis, we performed qRT-PCR to determine the expression of TGFßRIII in 10 pairs of HCC and corresponding normal tissues. As expected, 7 out of 10 selected HCCs had significantly reduced expression compared to the corresponding normal tissues; the remaining three had mean values of down-regulation (Fig. 2).

Genetic alterations and LOH analyses of TGFßRIII. The underlying mechanism for the down-regulation of TGFßRIII was studied in the HCC samples. The genetic alterations and LOH in the TGFßRIII gene were evaluated to determine the possible mechanism involved in the aberrant regulation of TGFßRIII. We screened mutations by SSCP and directsequencing of $67 \mathrm{HCCs}$ and 10 liver cancer-derived cell lines, as well as the normal liver cell line, THLE3. The results showed no significant mutations in any of the coding regions analyzed. However, we observed six polymorphisms in five exons that are summarized in Table II. Among these, there was one novel polymorphism, not previously identified, located in exon 13 (G2133A); however, the novel polymorphism was not associated with an amino acid substitution 
Table II. Genetic alterations of TGF $\beta R I I I$ gene in HCCs and liver cancer-derived cell lines.

\begin{tabular}{|c|c|c|c|c|c|c|c|}
\hline Exon & Nucleotide & Codon & Amino acid & Type & SNP ID & $\begin{array}{l}\text { Frequency } \\
\text { in tissues }\end{array}$ & $\begin{array}{l}\text { Cell } \\
\text { lines }\end{array}$ \\
\hline 2 & $\mathrm{C} 44 \mathrm{~T}$ & $\mathrm{TC} C \rightarrow \mathrm{T} \underline{\mathrm{TC}}$ & $\mathrm{S} 15 \mathrm{~F}$ & $\begin{array}{c}\text { Missense } \\
\text { (non-synonymous) }\end{array}$ & rs 1805110 & $\begin{array}{l}\text { TCC }(1 / 67) \\
\text { TTC }(66 / 67)\end{array}$ & \\
\hline 3 & A216G & $\mathrm{GC} \underline{\mathrm{A}} \rightarrow \mathrm{GC} \underline{\mathrm{G}}$ & A72A & $\begin{array}{c}\text { Silent } \\
\text { (synonymous) }\end{array}$ & rs2810904 & $\begin{array}{l}\text { GCA }(20 / 67) \\
\text { GCG }(47 / 67)\end{array}$ & $\begin{array}{l}\text { THLE3 } \\
\text { Hep3B } \\
\text { PLC/PRF/5 } \\
\text { SNU-354 } \\
\text { SNU-387 } \\
\text { SNU-423 } \\
\text { SNU-475 }\end{array}$ \\
\hline 5 & A519G & $\mathrm{TC} \underline{\mathrm{A}} \rightarrow \mathrm{TC} \underline{\mathrm{G}}$ & S173S & $\begin{array}{c}\text { Silent } \\
\text { (synonymous) }\end{array}$ & rs2306888 & $\begin{array}{l}\text { TCA }(47 / 67) \\
\text { TCG }(20 / 67)\end{array}$ & SNU-449 \\
\hline \multirow[t]{2}{*}{13} & T2028C & $\mathrm{TTT} \rightarrow \mathrm{TT} \underline{\mathrm{C}}$ & F676F & $\begin{array}{c}\text { Silent } \\
\text { (synonymous) }\end{array}$ & rs1805113 & $\begin{array}{l}\text { TTT }(56 / 67) \\
\text { TTC }(11 / 67)\end{array}$ & $\begin{array}{l}\text { HepG2 } \\
\text { SNU-182 }\end{array}$ \\
\hline & G2133A & $\mathrm{ACG} \rightarrow \mathrm{AC} \underline{\mathrm{A}}$ & $\mathrm{T} 711 \mathrm{~T}$ & $\begin{array}{c}\text { Silent } \\
\text { (synonymous) }\end{array}$ & Unknown & $\begin{array}{l}\mathrm{ACG}(66 / 67) \\
\mathrm{ACA}(1 / 67)\end{array}$ & \\
\hline 14 & $\mathrm{~T} 2247 \mathrm{C}$ & $\mathrm{AC} \underline{\mathrm{T}} \rightarrow \mathrm{AC} \underline{\mathrm{C}}$ & T749T & $\begin{array}{c}\text { Silent } \\
\text { (synonymous) }\end{array}$ & rs 284878 & $\begin{array}{l}\text { ACT }(18 / 67) \\
\operatorname{ACC}(49 / 67)\end{array}$ & $\begin{array}{l}\text { THLE3 } \\
\text { Hep3B } \\
\text { HepG2 } \\
\text { PLC/PRF/5 } \\
\text { SNU-182 } \\
\text { SNU-387 } \\
\text { SNU-423 } \\
\text { SNU-449 }\end{array}$ \\
\hline
\end{tabular}

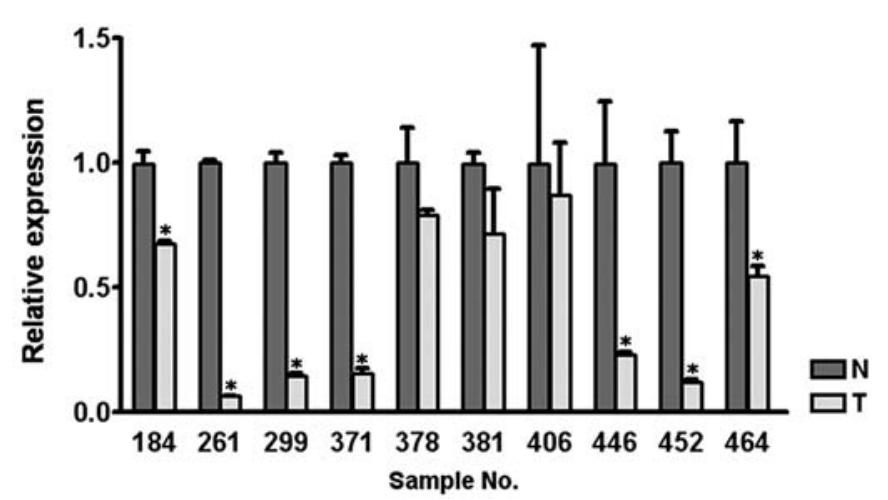

Figure 2. qRT-PCR analysis of TGFßRIII in HCC. Ten HCC samples were selected for the experiments. GAPDH was used as an internal control. The relative expression is presented as the mean value of duplicate results. ${ }^{*} \mathrm{P}<0.05$ by unpaired student's t-test performed using Microsoft ${ }^{\mathrm{TM}}$ Office Excel 2007 software.

(T711T). The nucleotide alterations found in exon 2 $(\mathrm{TCC} \rightarrow \mathrm{TTC})$ associated with changes in amino acids were found at high rates $(66 / 67,98.5 \%)$.

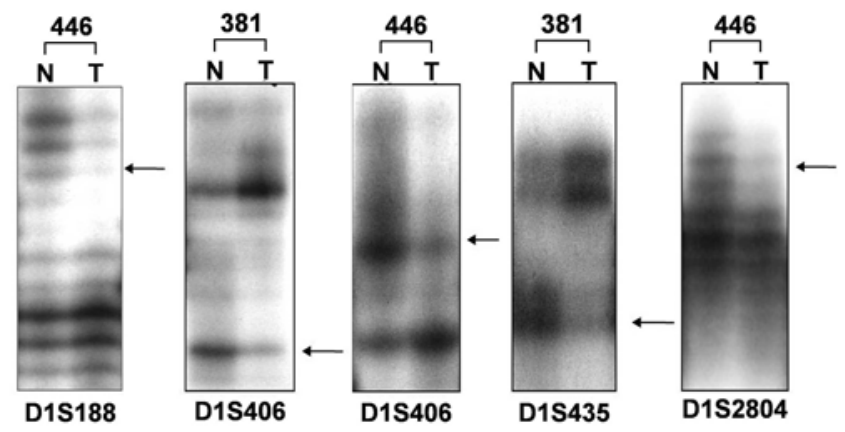

Figure 3. Results of the loss of heterozygosity with microsatellite markers D1S188, D1S406, D1S435 and D1S2804 (N, normal; T, tumor). Arrows indicate the alleles exhibiting $\mathrm{LOH}$. $\mathrm{LOH}$ was detected in two samples out of ten.

In addition, allelic loss at the TGF $\beta R I I I$ locus was studied with the microsatellite markers D1S188, D1S406, D1S435 and D1S2804, in ten normal and tumor sample sets analysed by qRT-PCR. LOH was observed in two samples (Fig. 3). 


\section{Discussion}

There is accumulating evidence indicating that TGFßRIII is genetically and functionally implicated in tumorigenesis. TGFßRIII maps to chromosome 1 p32, a region frequently deleted in a variety of human solid cancers (18). In addition, many known genes that map to this chromosomal region are thought to play a role in tumorigenesis (18). For example, when TGFßRIII was suppressed in pancreatic cancer cells, the endothelial to mesenchymal transition-related motility and invasiveness was increased (19). In addition, aberrant TGFßRIII regulation has been reported to be closely related to ovarian failure susceptibility (20). For ovarian cancer, the expression level of TGFßRIII was found to be decreased and did not suppress ovarian cancer cell proliferation, but inhibited motility and invasion (21). Furthermore, several studies have proposed that the TGFßRIII gene is a potent tumor suppressor by experiments that have shown loss of expression, frequent $\mathrm{LOH}$, and inhibition of cell motility and invasion in a variety of cancers including breast, prostate and non-small cell lung carcinomas (14-16). Consistent with previous results, our findings indicated that the expression level of TGFßRIII was gradually down-regulated during the development of HCC compared to corresponding normal tissues, implying that down-regulation of TGFßRIII may play a role in hepatocarcinogenesis (Figs. 1 and 2).

In many malignant cancers, it is well established that somatic mutation and/or $\mathrm{LOH}$ are associated with the tumorigenesis of neoplastic cells. However, our study on genetic alterations of the TGF $\beta R I I I$ gene did not show somatic mutations or a high frequency of LOH in the HCCs. These results suggest that somatic mutations and $\mathrm{LOH}$ are not the major causes for the down-regulation of TGFßRIII. There was one mutation detected in exon 2 (SNP ID: rs1805110) with an associated amino acid change; however, this alteration did not seem to be associated with downregulation of TGFßRIII, since it was not tumor-specific. However, this is the first study on polymorphisms of TGFßRIII in HCC. The findings suggest that this genetic alteration of TGFßRIII in HCC may be associated with the susceptibility for liver cancer among Korean patients. In our $\mathrm{LOH}$ experiments, we observed two cases of $\mathrm{LOH}$ out of all 10 HCC samples. It is possible that LOH at the TGFßRIII genomic locus is associated with the reduced expression of TGFßRIII in HCC. However, the low frequency of LOH suggests that it is not a major cause of the down-regulation of TGFßRIII in HCC.

TGF- $ß$ signaling has been implicated in cancer progression among many different types of cancer including hepatocarcinogenesis (22). Several studies have demonstrated that TGF- $\beta$ is overexpressed in HCC $(23,24)$. Furthermore, elevated levels of TGF- $\beta$ in the serum and urine have been shown to be closely related to a poor prognosis and tumor angiogenesis (25-27). TGFßRII and Smad 4 have been associated with weaker expression levels in HCC tissues when compared to adjacent normal tissues (24). In addition, disruption of TGF- $\beta$ signaling through the smad adaptor ELF (embryonic liver protein) has been shown to contribute to the development of HCC in an in vivo model (28). Although these findings suggest that TGF- $\beta$ signaling, through TGF- $\beta$ receptors, may play a role as a tumor suppressor in HCC progression and development, the involvement of TGFßRIII remains to be elucidated.

In summary, the results of this study showed that TGFßRIII was down-regulated in human HCC. In addition, six single nucleotide polymorphisms (SNPs) in five exons of the TGFßRIII gene were identified, among which one was not previously reported. Furthermore, loss of heterozygosity was detected at a low rate. The findings did not show that genetic alterations and $\mathrm{LOH}$ were associated with aberrant regulation of TGFßRIII in human HCC. Additional studies with functional analysis are needed to further define the role of TGFßRIII in hepatocarcinogenesis.

\section{Acknowledgements}

This study was supported by the Korean Ministry of the Environment via 'The Eco-technopia 21 project' and by the Korean Science and Engineering Foundation (KOSEF) via the Cell Death Disease Research Center at The Catholic University of Korea.

\section{References}

1. Bruix J, Boix L, Sala M and Llovet JM: Focus on hepatocellular carcinoma. Cancer Cell 5: 215-219, 2004.

2. Farazi PA and DePinho RA: Hepatocellular carcinoma pathogenesis: from genes to environment. Nat Rev Cancer 6: 674-687, 2006.

3. de La Coste A, Romagnolo B, Billuart P, et al: Somatic mutations of the beta-catenin gene are frequent in mouse and human hepatocellular carcinomas. Proc Natl Acad Sci USA 95: 8847-8851, 1998.

4. Pang A, Ng IO, Fan ST and Kwong YL: Clinicopathologic significance of genetic alterations in hepatocellular carcinoma. Cancer Genet Cytogenet 146: 8-15, 2003.

5. Satoh S, Daigo Y, Furukawa Y, et al: AXIN1 mutations in hepatocellular carcinomas, and growth suppression in cancer cells by virus-mediated transfer of AXIN1. Nat Genet 24: 245-250, 2000 .

6. Massague J: TGF-beta signal transduction. Annu Rev Biochem 67: 753-791, 1998.

7. Blobe GC, Schiemann WP and Lodish HF: Role of transforming growth factor beta in human disease. N Engl J Med 342: 1350-1358, 2000.

8. Wrana JL, Attisano L, Wieser R, Ventura F and Massague J: Mechanism of activation of the TGF-beta receptor. Nature 370: 341-347, 1994

9. Nakao A, Imamura T, Souchelnytskyi S, et al: TGF-beta receptor-mediated signalling through $\mathrm{Smad} 2, \mathrm{Smad} 3$ and Smad4. EMBO J 16: 5353-5362, 1997.

10. Wang XF, Lin HY, Ng-Eaton E, Downward J, Lodish HF and Weinberg RA: Expression cloning and characterization of the TGF-beta type III receptor. Cell 67: 797-805, 1991.

11. Derynck R and Feng XH: TGF-beta receptor signaling. Biochim Biophys Acta 1333: F105-F150, 1997.

12. Copland JA, Luxon BA, Ajani L, et al: Genomic profiling identifies alterations in TGFbeta signaling through loss of TGFbeta receptor expression in human renal cell carcinogenesis and progression. Oncogene 22: 8053-8062, 2003.

13. Florio P, Ciarmela P, Reis FM, et al: Inhibin alpha-subunit and the inhibin coreceptor betaglycan are downregulated in endometrial carcinoma. Eur J Endocrinol 152: 277-284, 2005.

14. Dong M, How T, Kirkbride KC, et al: The type III TGF-beta receptor suppresses breast cancer progression. J Clin Invest 117: 206-217, 2007.

15. Turley RS, Finger EC, Hempel N, How T, Fields TA and Blobe GC: The type III transforming growth factor-beta receptor as a novel tumor suppressor gene in prostate cancer. Cancer Res 67: 1090-1098, 2007.

16. Finger EC, Turley RS, Dong M, How T, Fields TA and Blobe GC: TbetaRIII suppresses non-small cell lung cancer invasiveness and tumorigenicity. Carcinogenesis 29: 528-535, 2008. 
17. Nam SW, Park JY, Ramasamy A, et al: Molecular changes from dysplastic nodule to hepatocellular carcinoma through gene expression profiling. Hepatology 42: 809-818, 2005.

18. Ragnarsson G, Eiriksdottir G, Johannsdottir JT, Jonasson JG, Egilsson V and Ingvarsson S: Loss of heterozygosity at chromosome $1 \mathrm{p}$ in different solid human tumours: association with survival. Br J Cancer 79: 1468-1474, 1999.

19. Gordon KJ, Dong M, Chislock EM, Fields TA and Blobe GC: Loss of type III transforming growth factor beta receptor expression increases motility and invasiveness associated with epithelial to mesenchymal transition during pancreatic cancer progression. Carcinogenesis 29: 252-262, 2008.

20. Dixit H, Rao KL, Padmalatha VV, et al: Mutational analysis of the betaglycan gene-coding region in susceptibility for ovarian failure. Hum Reprod 21: 2041-2046, 2006.

21. Hempel N, How T, Dong M, Murphy SK, Fields TA and Blobe GC: Loss of betaglycan expression in ovarian cancer: role in motility and invasion. Cancer Res 67: 5231-5238, 2007.

22. Martin J and Dufour JF: Tumor suppressor and hepatocellular carcinoma. World J Gastroenterol 14: 1720-1733, 2008.

23. Abou-Shady M, Baer HU, Friess H, et al: Transforming growth factor betas and their signaling receptors in human hepatocellular carcinoma. Am J Surg 177: 209-215, 1999.
24. Ji GZ, Wang XH, Miao L, et al: Role of transforming growth factor-beta1-smad signal transduction pathway in patients with hepatocellular carcinoma. World J Gastroenterol 12: 644-648, 2006.

25. Song BC, Chung YH, Kim JA, et al: Transforming growth factor-beta1 as a useful serologic marker of small hepatocellular carcinoma. Cancer 94: 175-180, 2002.

26. Tsai JF, Chuang LY, Jeng JE, et al: Clinical relevance of transforming growth factor-beta 1 in the urine of patients with hepatocellular carcinoma. Medicine (Baltimore) 76: 213-226, 1997.

27. Ito N, Kawata S, Tamura S, et al: Positive correlation of plasma transforming growth factor-beta 1 levels with tumor vascularity in hepatocellular carcinoma. Cancer Lett 89: 45-48, 1995.

28. Kitisin K, Ganesan N, Tang Y, et al: Disruption of transforming growth factor-beta signaling through beta-spectrin ELF leads to hepatocellular cancer through cyclin D1 activation. Oncogene 26: 7103-7110, 2007. 